Nevşehir Bilim ve Teknoloji Dergisi TARGid Özel Sayı 411-421 2016

DOI: 10.17100/nevbiltek.211014

URL: http://dx.doi.org/10.17100/nevbiltek.211014

\title{
Kültür Levrek (Dicentrarchus labrax, L.) Balıklarından İzole Edilen Vibrio harveyi Suşlarının Antimikrobiyal Duyarlılıkları Üzerine Bir Çalışma
}

\author{
Jale Korun* \\ Akdeniz Üniversitesi, Su Ürünleri Fakültesi, Yetiştiricilik Bölümü, Antalya
}

Öz

Mevcut çalışmada, hasta levrek balıklarından izole edilen Vibrio harveyi suşlarının in vitro koşullarda ve iki farklı sıcaklık derecesinde antimikrobiyallere karşı duyarlılıkları tespit edilmiştir. Levrek balıkları Bodrum civarındaki ticari bir işletmeden temin edilmiştir. Balıklara işletme koşullarında nekropsi uygulanmıştır. İç organlardan ekim yapıldıktan sonra, besiyerleri $22 \pm 2{ }^{\circ} \mathrm{C}$ de 72 saat için inkübe edilmiştir. Bu süre sonunda, besiyerlerinde gelişen bakteri kolonilerini tanımlamak amacı ile fenotipik testler ve API 20NE hızlı tanı kit şeritleri de kullanılmıştır. V. harveyi ATCC 33868 kontrol suşu da çalışmalara dahil edilmiştir. Bakteri suşlarının antibiyotik duyarlılıklarının tespiti için standart disk difüzyon yöntemi kullanılmıştır. Testler $22 \pm 2{ }^{\circ} \mathrm{C}$ ve $28 \pm 2{ }^{\circ} \mathrm{C}$ de yapılmıştır. Bakteriyolojik çalışma sonuçlarına göre, $13 \mathrm{~V}$. harveyi suşu izole ve identifiye edilmiştir. Suşların $22 \pm 2{ }^{\circ} \mathrm{C}$ de ampisilin, basitrasin, streptomisin ve sulfametoksazol'e dirençli oldukları tespit edilmiştir. Bununla birlikte, suşlar aynı sıcaklık derecesinde furazolidon ve flumekuin'e hassasiyet göstermiştir. $28 \pm 2{ }^{\circ} \mathrm{C}$ de suşlar basitrasin ve sulfametoksazol'e dirençli oldukları bulunmuştur. CLSI sucul hayvanlardan izole edilen bakteri türlerinin antibiyotik hassasiyetlerinin tespitinin iki farklı sıcaklık derecesinde yapılmasını önermiştir. Ancak, her iki sıcaklık derecesinde yapılan çalışmalarda, sıcaklığın test sonuçlarını değiştirebileceği anlaşılmıştır.

Anahtar Kelimeler: Levrek, Vibrio harveyi, antimikrobiyal duyarlılık

\section{A Study on Antimicrobial Susceptibilities of Vibrio harveyi Strains Isolated from the Cultured Sea Bass (Dicentrarchus labrax, L.)}

\begin{abstract}
In the present study, the susceptibilities of Vibrio harveyi strains isolated from the diseased sea bass against antimicrobials were determined in vitro conditions and at two different temperatures. The sea bass were taken from a commercial fish farm around Bodrum. Necropsy to fish was applied at the farm's condition. After inoculations from internal organs were made, the Petri dishes were incubated at $22 \pm 2{ }^{\circ} \mathrm{C}$ for 72 hours. At the end of this time, to identify the bacterial colonies which were grown on the media phenotypic tests and API 20NE rapid identification kit strips were also used. V. harveyi ATCC 33865 as a control strain was included into the studies. For detection of antimicrobial susceptibilities of the bacterial strains standard disc diffusion method was used. Tests were made at $22 \pm 2{ }^{\circ} \mathrm{C}$ and $28 \pm 2{ }^{\circ} \mathrm{C}$. According to the results of bacteriological studies, $13 \mathrm{~V}$. harveyi strains were isolated and identified. It was detected the strains were resistant to ampicillin, bacitracin, streptomycin and sulfamethoxazole at $22 \pm$ $2{ }^{\circ} \mathrm{C}$. However, the strains showed susceptibility to furazolidone and flumequine at the same temperature. It was found the strains were resistance against bacitracin and sulfamethoxazole at $28 \pm 2{ }^{\circ} \mathrm{C}$. CLSI have suggested that antibiotic susceptibility of the bacterial strains isolated from aquatic animals were carried out at two different temperatures. But it was understood the temperature might be change the test results which were done at the two temperatures.
\end{abstract}

* e-mail: jalekorun@akdeniz.edu.tr 
Korun J.

\section{Giriş}

Yüzücü sallardan asılan kafeslerdeki deniz balıklarının yetiştiriciliği Japonya da 1950’li yıllarda, Güneydoğu Asya da ise 1970’li yıllarda başlamıştır. Bu ilk yıllarda, kültür amaçlı olarak balıklar doğadan temin edilmiştir. Dünyanın birçok bölgesinde bu durum hali hazırda devam etmekte olup, bugün bazı balık türlerinin yetiştiriciliği ise kuluçkahanelerde başarılı bir şekilde yapılmaktadır. Kafes kültür sistemleri ve yoğun deniz balıkları yetiştiriciliği nerede uygulanırsa uygulansın tüm dünyada temel olarak benzerdir [1]. Ülkemizde deniz balıkları yetiştiriciliği 1980'li yıllarda Ege Bölgesi’nde başlamıştır. Başlangıçta yetiştiricilik çalışmaları denizden yakalanan yavru balıkların kafeslerde yetiştirilmesi iledir. Deniz balıklarının yavru yetiştiriciliğine yönelik kuluçkahanelerin kurulması ve bunların işletme ihtiyacına cevap verecek düzeye erişmesi ile 2000 yılından itibaren doğadan toplama yöntemi tamamen yasaklanmıştır [2]. Ülkemizde deniz balıklarının yetiştiriciliği birkaç türle sınırlı olup bu türler arasında Avrupa levreği (Dicentrarchus labrax) da yer almaktadır [3]. TUİK verilerine göre kültür yolu ile elde edilen levrek balıklarının üretim miktarları Tablo 1 de verilmiştir [4].

Tablo 1. Yetiştiricilik yolu ile elde edilen levrek üretim miktarları [3 ve 4]

\begin{tabular}{lll}
\hline Yllar & Üretim Miktarı (Ton) \\
1988 & 5 \\
1990 & 102 \\
1992 & 808 \\
1994 & 2229 \\
1996 & 5210 \\
2000 & 17877 \\
2002 & 14339 \\
2004 & 26297 \\
2006 & 38408 \\
2008 & 49270 \\
2010 & 50796 \\
2012 & 65512 \\
& 67912 \\
\hline
\end{tabular}

Balıklarda hastalıklara neden olan patojenik ajanlar gerek doğal gerekse kültür koşullarında da mevcuttur. Bununla birlikte, patojenik ajanlar doğal ortamlarda nadiren balık kayıplarına neden olurlar. Kültür levrek balıkları başlıca Gram-negatif bakteri türleri tarafından etkilenmektedir [5-8]. Bu hastalık etkenleri Tablo 2 de verilmiştir. 
Tablo 2. Levrek balıklarının kültürünü etkileyen başlıca Gram-negatif bakteriyel patojenler

\begin{tabular}{cc}
\hline Etken & Hastalık \\
Listonella anguillarum (önceden Vibrio anguillarum) & Listonellozis \\
$\begin{array}{c}\text { Photobacterium damselae subsp. piscicida (önceden Pasteurella } \\
\text { piscicida) } \\
\text { Tenacibaculum maritimum } \\
\text { V. alginolyticus } \\
\text { V. harveyi } \\
\text { V. damselae (yeni isimlendirme Ph. damselae subsp. damselae) }\end{array} \quad$ Vibriyozis \\
\hline
\end{tabular}

Kültür levrek balıklarını etkileyen bakteriyel enfeksiyonlardan vibriosiz, tüm dünyada deniz balıklarının en ciddi hastalıklarından bir tanesidir [9]. Bu hastalıktan etkilenen başlıca balık türleri arasında yılan balıkları (Anguilla japonica ve A. anguilla), morina (Gadus morhua), çipura (Sparus aurata), Avrupa levreği (Dicentrarchus labrax), kalkan (Scophthalmus maximus), Pasifik (Oncorhynchus spp.) ve Atlantik (Salmo salar) salmon balıkları da yer alır [10]. Balıklarda durgunluk, iştahsızlık, vücudun çeşitli yerlerinde, yüzgeçlerin taban kısımlarında hemoraji, ekzoftalmus, korneal opaklık, solgun solungaçlar, karın kısmında şişkinlik, karaciğerde solgunluk, dalakta büyüme, mide-barsak içeriğinin gıda yönünden boş olması ve sarımsı renkli sıvı içermesi klasik vibriozis de gözlenen bulgulardır [10]. Klasik vibriozis'e neden olan türler olarak Listonella (Vibrio) anguillarum, V. ordalii, V. salmonicida ve $V$. vulnificus biyotip 2'nin bildirilmesine karşın, son yıllarda diğer Vibrio türleri örneğin $V$. alginolyticus, $V$. harveyi ve $V$. fluvialis da hastalık etkeni olarak bildirilmiştir [10 ve 11]. V. harveyi ilk kez kahverengi köpek balığı (Carcharhinus plumbeus)'ndan izole ve identifiye edilmiştir [12]. Türün daha sonraları levrek, çipura, dil (Solea senegalensis) balığı, sinagrit (Dentex dentex), kırmızı mercan (Pagellus erythrinus), mercan (Pagrus pagrus) ve sarıkuyruk (Seriola dumerili) balıklarından izole edildiği de bildirilmiştir [13]. V. harveyi'den kaynaklanan hastalık durumlarında balıklarda düzensiz yüzme davranışı, vücut deri renginde koyulaşma, ekzoftalmus ve internal hemorajiler gözlenir [13].

Hastalık türleri ve ciddiyeti büyük ölçüde balığın türü, kültür koşulları ve işletme yönetimi ile etkilenmektedir. Yüzer kafeslerde kültürü yapılan balıklar sıcaklık, tuzluluk, çözünmüş oksijen ve sudaki asılı partiküller gibi çevresel parametrelerin aniden ya da yaygın bir şekilde değişmesi durumunda hastalığa karşı hassas hale gelir [1]. Balıklarda sıklıkla gözlenen enfeksiyonlar arasında yer alan bakteriyel enfeksiyonların tedavisi genellikle antimikrobiyal ilaçlar kullanılarak yapılmaktadır [14]. Etken mikroorganizma üzerine antimikrobiyal ajanın in vitro aktivitesi hastalığın tedavisinde göz önüne alınması gereken faktörler arasında yer alır [15]. Bir antibiyotiğin antimikrobiyal aktivitesinin saptanması amacı ile uygulanan in vitro yöntemlere genel olarak 'duyarlılık testleri' adı verilir. Antimikrobiyal ilaçlara duyarlıllk birçok yöntem ile saptanabilmekte olup, bu yöntemler genel olarak iki başlık altında toplanabilir. Bunlar 1-direnç fenotipinin belirlendiği yöntemler ve 2-genotipik yöntemler’dir [15]. Direnç fenotipinin belirlendiği yöntemlere inhibitör aktivite ile ilgili testler, katı veya sıvı besiyerinde sulandırım 
Korun J.

(dilüsyon) yöntemi, disk difüzyon yöntemi, E testi ve antimikrobiyal ajanları inaktive eden enzimlerin saptandığı yöntemler dahildir. Genotipik yöntemler ise doğrudan direnç genlerinin saptanabildiği yöntemlerdir [15].

Sucul canlılardan izole edilen bakteri türlerinin antimikrobiyal duyarlılıklarının tespitinde disk difüzyon yöntemi kullanılmaktadır [16-19]. Jakaprakash vd. [16] hasta Macrobrachium rosenbergii larvalarından izole ettikleri Vibrio alginolyticus suşlarının \%1.5 NaCl eklenerek hazırlanan MuellerHinton agarda disk difüzyon yöntemine göre ampisilin, eritromisin, kloramfenikol, oksitetrasiklin ve tetrasiklin’e dirençli, streptomisin, rifampisin, neomisin, kanamisin, siplofloksazin, furazolidon, nitrofurantoin, ve trimethoprim'e hassas olduklarını bildirmiştir. Li vd. [17] Hong Kong ta gümüş mercan (Sparus sabra) balıklarından 24'ü V. alginolyticus, 12'si V. vulnificus, 7'si V. parahaemolyticus, 7'si V. parahaemolyticus, 4'ü $V$. logei, 2'si $V$. pelagius II, 1'i $V$. fluvialis ve 1'i $V$. mediterranei olmak üzere toplam 51 patojenik Vibrio suşunu izole ettiklerini çalışmalarında, suşların hepsinin ceftriaxone, streptomisin, nalidiksik asit ve rifampisin'e hassas olduklarını, çoğu suşun ise ampisilin, cefuroxime, amikasin, kanamisin ve trimetoprim’e dirençli olduklarını rapor etmiştir. Nakayama vd. [18]. karideslerden izole ettikleri $3 \mathrm{~V}$. harveyi suşunun kanamisin, oksitetrasiklin, karbenisilin ve ampisilin’e dirençli olduklarını, Redondo vd. [19] ise Carassius auratus balıklarından izole ettikleri V. fluvialis suşlarının ampisilin, tetrasiklin, nitrofurantoin ve kanamisin'e direnç gösterdiklerini belirtmiştir.

CLSI [20] sucul hayvanlardan izole edilen bakterilerin antimikrobiyal duyarlılık testlerinin iki farklı sıcaklık derecesinde yapılmasını önermiştir. Mevcut çalışmanın amacı; hasta levrek balıklarından izole edilen $V$. harveyi suşlarının iki farklı sıcaklık derecesinde ve in vitro koşullarda gerçekleştirilen antibiyotiklere olan duyarlılıklarını tespit etmektir.

\section{Materyal ve Metot}

\subsection{Araştırmanın yapıldığı yer ve balık materyali}

Çalışma Bodrum civarında bulunan ticari deniz balığı üretim işletmesinde gerçekleştirilmiştir. Örnekleme sırasında deniz suyu sıcaklığg $13 \pm 2{ }^{\circ} \mathrm{C}$ olarak, tuzluluk ise $\%_{0} 38$ olarak ölçülmüştür. Çalışmada 250-300 g ağırlığında 15 hasta levrek balığı materyal olarak kullanılmıştır. Hasta balıklardan izole edilen bakterilerin tanımlanması için gerekli bakteriyolojik çalışmalar, Akdeniz Üniversitesi Su Ürünleri Fakültesi araştırma laboratuarında yapılmıştır.

\subsection{Nekropsi}

Hasta balıkların ăg kafeste sergilemiş oldukları davranışlar tespit edildikten sonra, karada çalışma ortamına nakledilmiştir. Balıklar anestezik solüsyonda (1.5 ml 2-phenoxyethanol / $1 \mathrm{~L}$ deniz suyu) hareketleri durana kadar bekletilmiştir. Balıklardaki klinik bulgular kaydedildikten sonra, vücut yüzeyleri \%70 etil alkol ile silinerek dezenfekte edilmiştir. Nekropsi sonrası, balıklarda gözlenen iç bulgular kaydedilmiştir [21]. 


\subsection{Bakteri izolasyonu}

Hasta levrek balıklarına nekropsi uygulandıktan sonra, balıkların karaciğer, dalak, böbrek gibi iç organlarından \%1.5 NaCl ilave edilerek hazırlanan ticari BHIA besiyerlerine ekimler yapılmıştır. Ekim yapılan besiyerleri $22 \pm 2{ }^{\circ} \mathrm{C}$ de 72 saat süre ile inkübe edilmiştir [22]. Belirtilen süre sonunda besiyerlerinde gelişme gösteren bakteri kolonilerinden alt kültürler hazırlanmıştır.

\subsection{Bakterilerin tanımlanması}

Bakterilerin tanımlanması amacı ile yapılan fenotipik test çalışmaları için kullanılan tüm besiyerleri \%1.5-2 oranında $\mathrm{NaCl}$ eklenerek hazırlanmış ve besiyerleri $22 \pm 2{ }^{\circ} \mathrm{C}$ de $48-72$ saat süre ile inkübe edilmiştir. Çalışmada konvansiyonel tanı testleri olarak Gram boyama, hareketlilik, sitokrom oksidaz ve katalaz testleri, O/F glükoz buyyonunda fermentasyon testi, Voges-Proskauer ve metil kırmızısı testleri, Simmon's sitrat, ONPG, TCBS de gelişme, vibriostat testi (10 $\mu \mathrm{g}$ ve $150 \mu \mathrm{g})$, farklı tuzluluk oranlarında gelişme $(0,2,4,6,8$ ve 10), farklı sıcaklık derecelerinde gelişme $(4,22,30,35$ ve 40), TSI da $\mathrm{H}_{2} \mathrm{~S}$ üretimi, glükozdan gaz oluşumu, ß-hemoliz, arjinin dihidrolaz, ornitin ve lizin dekarboksilaz üretimleri, amilaz, jelatinaz, nitratı indirgeme, şekerlerden asit üretimi, kabarma ve MacConkey agarda gelişme testleri uygulanmıştır [22 ve 23]. Bakterilerin tanımlanmasında ayrıca API 20NE hızlı tanı kiti de üretici firmanın (BioMerieux, France) tavsiyeleri doğrultusunda hazırlanarak kullanılmıştır. Bakteri suş profilleri APIWEB identification software'e göre değerlendirilmiştir. Çalışmalara ayrıca referans suş olarak V. harveyi (ATCC 33868) de dahil edilmiştir.

\subsection{Standart disk difüzyon yöntemi ile bakteri suşlarının antibiyogram hassasiyetlerinin tespiti}

Bakteriyel izolatların in vitro hassasiyetleri CLSI [20]'e göre disk agar difüzyon yöntemi ile tespit edilmiştir. Çalışmaya Escherichia coli (ATCC 25922) kalite kontrol suşu olarak dahil edilmiştir. 24 ila 28 saatlik kültürden alınarak bakteriler \%1.5 $\mathrm{NaCl}$ içeren nütrient buyyonda süspanse edilmiştir. Bakteriyel süspansiyon tuzlu Mueller-Hinton agarlı besiyerinin yüzeyine yayılmadan önce, süspansiyonun bulanıklığı $0.5 \mathrm{McFarland}$ ünitesi $\left(1.5 \times 10^{8} \mathrm{CFU} / \mathrm{ml}\right)$ olacak şekilde ayarlanmıştır. Testler $22 \pm 2{ }^{\circ} \mathrm{C}$ ve $28 \pm 2{ }^{\circ} \mathrm{C}$ olacak şekilde iki farklı sıcaklık derecesinde yapılmıştır. Yukarıda belirtilen sıcaklık derecelerinde, petri kutuları 24 ila 28 saat süre ile inkübe edilmiştir. Çalışmada kullanılan antibiyotik diskleri; ampisilin (10 $\mu \mathrm{g})$, basitrasin (0.04 $\mu \mathrm{g})$, eritromisin (15 $\mu \mathrm{g})$, furazolidone (15 $\mu \mathrm{g})$, flumequine (30 $\mu \mathrm{g})$, kanamisin (30 $\mu \mathrm{g})$, kloramfenikol (30 $\mu \mathrm{g})$, nalidiksik asit (30 $\mu \mathrm{g})$, oksalinik asit (2 $\mu \mathrm{g})$, oksitetrasiklin $(30 \mu \mathrm{g})$, streptomisin $(10 \mu \mathrm{g})$, sülfametoksozal (25 $\mu \mathrm{g})$, sülfonamidler (300 $\mu \mathrm{g})$, tetrasiklin (30 $\mu \mathrm{g}$ ) ve trimetoprim (5 $\mu \mathrm{g})$ 'dir. Tüm disk difüzyon testleri iki tekrarlı olacak şekilde gerçekleştirilmiştir. Antibiyotik diskleri etrafındaki zon çapları ölçülerek kaydedilmiş ve ortalamaları alınmıştır. Veriler analiz edilerek gerek hasta levrek balıklarından gerekse kalite kontrol suşundan elde edilen test sonuçlarına göre suşlar hassas, orta dirençli ve dirençli olmak üzere tanımlanmıştır [20 ve 24]. 
Korun J.

\section{Bulgular}

\subsection{Hasta balıkların klinik ve nekropsi bulguları}

Yapılan klinik muayenede balıklarda durgunluk, iştahsızlık, solunum güçlüğü, yüzgeçlerde erime, ekzoftalmus, ağızda, operkulumlarda, yüzgeçlerin taban kısımlarında ve anal bölge etrafinda hemorajiler gözlenmiştir. İç bakıda ise dalakta büyüme ve renginde koyulaşma, barsak duvarında hemoraji, böbrekte solgunluk ayrıca mide-barsak kısmının gıda yönünden boş olduğu da tespit edilmiştir.

\subsection{Bakteriyolojik çalışma sonuçları}

Çalışmada izole edilen bakteri suşları Alsina ve Blanch [25], Farmer vd. [26] ve Noguerola ve Blanch [27]'a göre identifiye edilmiştir. Yapılan bakteriyolojik çalışma sonuçlarına göre izole edilen suşlar Vibrio harveyi olarak tanımlanmıştır. Bakteri suşlarının API 20NE hızlı tanı kiti test sonuçlarına göre izole edilen bakteriler 5476744 profil numarası ile $V$. harveyi olarak tanımlanmıştır. Bakteriyolojik çalışma sonuçları Tablo 3 ve 4'te verilmiştir.

Tablo 3. Çalışmada izole edilen Vibrio harveyi suşlarının fenotipik test sonuçları

\begin{tabular}{|c|c|c|}
\hline Testler & $\begin{array}{l}\text { Vibrio harveyi (saha izolatları, } 13 \\
\text { izolat) }\end{array}$ & $\begin{array}{l}\text { Referans suş, } V . \text { harveyi (ATCC } \\
\text { 33868) }\end{array}$ \\
\hline Gram boyama & - & - \\
\hline Hareketlilik & + & + \\
\hline Sitokrom oksidaz & + & + \\
\hline Katalaz & + & + \\
\hline O/F glükoz & Fermentatif & Fermentatif \\
\hline Metil kırmızısı & + & + \\
\hline Voges-Proskauer & - & - \\
\hline ONPG & + & + \\
\hline TCBS de gelişme &,+ sarı &,+ sar1 \\
\hline Vibriostat (10 $\mu \mathrm{g})$ & Hassas & Hassas \\
\hline Vibriostat $(150 \mu \mathrm{g})$ & Hassas & Hassas \\
\hline Sitrat & - & - \\
\hline İndol üretimi & + & + \\
\hline ß-hemoliz & + & + \\
\hline Glükozdan gaz oluşumu & - & - \\
\hline Ornitin dekarboksilaz & + & - \\
\hline Lizin dekarboksilaz & + & + \\
\hline Arjinin dihidrolaz & - & - \\
\hline Amilaz & + & + \\
\hline Jelatinaz & + & + \\
\hline Nitratı indirgeme & + & + \\
\hline \multicolumn{3}{|l|}{ Şekerlerden asit üretimi: } \\
\hline Glükoz & + & + \\
\hline Laktoz & - & - \\
\hline D-mannitol & + & - \\
\hline Sorbitol & - & - \\
\hline Myo-inositol & - & - \\
\hline D-ksiloz & - & - \\
\hline Raffinoz & - & - \\
\hline
\end{tabular}




\begin{tabular}{|c|c|c|}
\hline L-arabinoz & - & - \\
\hline Fruktoz & - & - \\
\hline D-mannoz & + & - \\
\hline Galaktoz & + & - \\
\hline Kabarma (swarming) & $\mathrm{D}^{*}$ & - \\
\hline $\begin{array}{l}\text { MacConkey agarda } \\
\text { gelişme }\end{array}$ & + & + \\
\hline \multicolumn{3}{|l|}{ Tuzlulukta gelişme } \\
\hline$\% 0 \mathrm{NaCl}$ & - & - \\
\hline$\% 2 \mathrm{NaCl}$ & + & + \\
\hline$\% 4 \mathrm{NaCl}$ & + & + \\
\hline$\% 6 \mathrm{NaCl}$ & + & + \\
\hline$\% 8 \mathrm{NaCl}$ & + & - \\
\hline$\% 10 \mathrm{NaCl}$ & - & - \\
\hline \multicolumn{3}{|l|}{ Sıcaklıkta gelişme } \\
\hline $4^{\circ} \mathrm{C}$ & - & - \\
\hline $22^{\circ} \mathrm{C}$ & + & + \\
\hline $30^{\circ} \mathrm{C}$ & + & + \\
\hline $35^{\circ} \mathrm{C}$ & + & + \\
\hline $40^{\circ} \mathrm{C}$ & $\mathrm{D}^{*}$ & + \\
\hline $\mathrm{H}_{2} \mathrm{~S}$ üretimi & - & - \\
\hline
\end{tabular}

* D: izolata bağlı olarak değişen sonuç

Tablo 4. API 20NE hızlı tanı kiti sonuçları

\begin{tabular}{ccc}
\hline Testler & V. harveyi saha izolatları (13 izolat) & V. harveyi (ATCC 33868) \\
\hline NO $_{3}$ & + & + \\
TRP & + & + \\
GLU & + & + \\
ADH & - & - \\
URE & - & - \\
ESC & + & + \\
GEL & + & + \\
PNG & + & + \\
GLU & + & Zaylf \\
ARA & - & - \\
MNE & $+/-$ & + \\
MAN & + & + \\
NAG & $+/-$ & + \\
MAL & $+/-$ & + \\
GNT & + & + \\
CAP & - & - \\
ADI & - & - \\
MLT & + & + \\
CIT & - & - \\
PAC & - & + \\
OX & + & + \\
\hline & & + \\
\hline
\end{tabular}


Korun J.

\subsection{Standart disk difüzyon yöntemi ile bakteri suşlarının antibiyogram hassasiyet sonuçları}

Çalışmada izole edilen $13 \mathrm{~V}$. harveyi suşunun $22 \pm 2{ }^{\circ} \mathrm{C}$ de gerçekleştirilen antibiyogram hassasiyetini belirleme çalışmalarında; suşların ampisilin, basitrasin, streptomisin ve sulfametoksazol'e dirençli oldukları tespit edilmiştir. 10 suş eritromisin'e orta dirençli ( $\leq 21 \mathrm{~mm}), 3$ suşun ise aynı antibiyotiğe hassas oldukları bulunmuştur. Ayrıca suşların furazolidon, flumekuin, kloramfenikol ve nalidiksik asit'e hassas oldukları da tespit edilmiştir. Çalışılan suşlardan $4 V$. harveyi suşunun oksitetrasiklin'e hassas ( $\geq 35 \mathrm{~mm}$ ) oldukları, geriye kalan diğer suşların ise orta dirençli oldukları bulunmuştur. 13 suştan $1 \mathrm{~V}$. harveyi suşu oksalinik asit'e direnç ( $\leq 28 \mathrm{~mm})$ gösterirken, 4 suş aynı antibiyotiğe orta direnç, geriye kalan suşlar ise hassasiyet göstermiştir. Çalışmada izole edilen $13 \mathrm{~V}$. harveyi suşunun $28 \pm 2{ }^{\circ} \mathrm{C}$ de gerçekleştirilen antibiyogram hassasiyetini belirleme çalışmalarında; suşların ampisilin, flumekuin, furazolidon, kloramfenikol, nalidiksik asit ve sulfametoksazol'e hassas oldukları tespit edilmiştir. Suşlar basitrasin ve streptomisin’e direnç göstermiştir. Çalışılan 13 V. harveyi suşundan 2 suşun oksalinik asit'e hassas, diğer suşların ise orta dirençli oldukları bulunmuştur. Suşların hepsi trimetoprim'e orta direnç göstermiştir. $5 \mathrm{~V}$. harveyi suşu eritromisin'e orta dirençli iken, aynı sıcaklık derecesinde 8 suşun ise aynı antibiyotiğe hassas oldukları tespit edilmiştir. Escherichia coli (ATCC 25922) kalite kontrol suşunun $22 \pm 2{ }^{\circ} \mathrm{C}$ ve $28 \pm 2{ }^{\circ} \mathrm{C}$ de gerçekleştirilen antibiyogram duyarlılık testlerinde suşun basitrasin'e dirençli, kloramfenikol, flumekuin, kanamisin, nalidiksik asit, streptomisin, tetrasiklin ve trimetoprim'e hassas olduğu bulunmuştur. Kalite kontrol suşu $22 \pm 2{ }^{\circ} \mathrm{C}$ de sulfametoksazol'e hassas iken, $28 \pm 2{ }^{\circ} \mathrm{C}$ de yapılan testlerde ise aynı antibiyotiğe karşı dirençli olduğu bulunmuştur.

\section{Tartışma ve Sonuç}

V. harveyi suşlarının iki farklı sıcaklık derecesinde ve in vitro koşullarda antibiyotiklere olan duyarlılıklarının tespitinin amaçlandığ sulfametoksazol'e direnç gösterdikleri, $28 \pm 2{ }^{\circ} \mathrm{C}$ de ise aynı antibiyotiklere hassas oldukları belirlenmiştir. Suşlar her iki sıcaklık derecesinde de basitrasin ve streptomisin’e dirençli oldukları bulunmuştur. Husain [28] basitrasin'in streptokoklar, Staphylococcus aureus dahil olmak üzere Grampozitif bakterileri inhibe ettiğini ayrıca bu antibiyotiğin bazı Gram-negatif bakteri türleri üzerinde de etkili olduğunu bildirmiştir. Jayasudha vd. [29] ve Orozoua vd. [30] isimli araştırıcılar farklı Gramnegatif balık patojeni bakteriler ile yapmış oldukları çalışmalarında, basitrasin'in bu bakteri türleri üzerinde etkili olmadığını bildirmiştir. Çalışmamızda da basitrasin’le ilgili olarak elde ettiğimiz bulgular yukarıda belirtilen araştırmacıların bulguları ile uyumlu olduğu anlaşılmıştır. Miller vd. [31] eritsomisin’in Gram-pozitif bakteri türleri üzerine etkili olduğunu belirterek, in vitro koşullarda ve iki farklı sıcaklık derecesinde ( $22 \pm 2{ }^{\circ} \mathrm{C}$ ve $28 \pm 2{ }^{\circ} \mathrm{C}$, sirası ile) E. coli ve Aeromonas salmonicida subsp. salmonicida'ya karşı etkili olduğunu bildirmiştir. Çalışmamızda 13 V. harveyi suşundan 10’unun bu antibiyotiğe orta dirençli iken, geriye kalan 3 suşun ise hassas oldukları tespit edilmiştir. CLSI [20] standartlarında balık patojenleri için iki farklı sıcaklık derecelerinde antimikrobiyal duyarlılık çalışmalarının yapılması önerilmektedir. Bununla birlikte, sucul hayvanlardan izole edilen bakteri türlerinin çoğunluğu için uzun süreli inkübasyon süresi ( $\geq 24$ saat) ve düşük inkübasyon sıcaklıklarına (28 $\left.{ }^{\circ} \mathrm{C}\right)$ gereksinim duyulur [32]. Bazı durumlarda ise örneğin Flavobacterium psychrophilum ve 
Piscirickettsia salmonis bakterileri ile yapılan çalışmalarda olduğu gibi $22^{\circ} \mathrm{C}$ ve daha düşük inkübasyon sıcaklıklarında ve daha uzun süreli olarak (en az 48 saat) inkübe edilmeleri gerekir [32 ve 33]. Yapılan çalışma sonuçlarına göre, suşların hassasiyet durumları çalışılan sıcaklık derecelerine göre farklılık gösterdiği ve sıcaklık derecelerinin antimikrobiyal test sonuçlarını etkilediği anlaşılmıştır. Sonuç olarak, antimikrobiyal duyarlılık testlerinde inkübasyon sıcaklıkları olarak hastalık çıkışlarının yaşandığı su sıcaklık derecelerinin göz önüne alınması daha etkili olacaktır.

\section{Kaynaklar}

[1] Seng L. T., Colorni A., "Infectious Diseases of Warmwater Fish in Marine and Brakish Waters", Edited by Woo P. T. K., Bruno D. W., Lim L. H. S., CABI Publishing, UK, 193-231, 2002

[2] Aydın F., Köksal G., Demir N., Bekcan S., Kırkağaç M., Gözgözoğlu E., Erbaş S., Deniz H., Maltaş $\mathrm{O}$, Arpa $\mathrm{H}$., "Su ürünleri yetiştiriciliği ve politikalar", www.abveteriner.org/dosyalar/supolitikalar.pdf, 2005

[3] Çelikkale M. S., Düzgüneş E., Okumuş İ., “Türkiye Su Ürünleri Sektörü, Potansiyeli, Mevcut Sorunları ve Çözüm Önerileri”, İstanbul Ticaret Odası, 414s, İstanbul, 1999

[4] TUiK, “Türkiye istatistik Kurumu, Su Ürünleri Verileri, 2014

[5] Güralp H., "Deniz Kültür Levrek Balıklarında Görülen Bakteriyel Patojenlerin Teşhisi ve Antibakteriyel Maddelere Duyarlılıklarının Belirlenmesi” İstanbul Üniversitesi, Fen Bilimleri Enstitüsü, Yükseklisans tezi, 143s, İstanbul, 2012

[6] Korun J., Timur G., “ Marine vibrios associated with diseased sea bass (Dicentrarchus labrax) in Turkey” JournalofFisheriesSciences.com, 2, 66-76

[7] Botella S., Pujalte M., Macián J., Garay E., “Amplified fragmant lenght polymorphism (AFLP) and biochemical typing of Photobacterium damselae subsp. damselae" Journal of Applied Microbiology, 93, 681-688, 2002

[8] Santos Y., Pazos F., Bandini I., Toranzo A. E., "Analysis of antigens present in the extracellular products and cell surface of Vibro anguillarum serotypes 01, 02, and 03” Applied Enviromental Microbiology, 61, 2493-2498, 1995

[9] Liu P. C., Lin J. Y., Chuang W. H., Lee K. K., "Isolation and characterization of pathogenic Vibrio harveyi ( $V$. carchariae) from the farmed marine cobia fish Rachycentron canadum L. with gastroenteritis syndrome” World Journal of Microbiology \& Biotechnology, 20, 495-499, 2004

[10] Toranzo A. E., Magarinos B., Romalde J. L., "A review of the main bacterial fish diseases in mariculture systems” Aquaulture, 246, 37-61, 2005

[11] Snoussi M., Noumi E., Hajlocui H., Usai D., Sechi L. A., Zanetti S., Bakhrouf A., "High potential of adhesion to abiotic and biotic materials in fish aquaculture facility by Vibrio alginolyticus strains” Journal of Applied Microbiology, 106, 1591-1599, 2009

[12] Grimes D. J., Stemmler J., Hada H., May E. B., Maneval D., Hetrick F. M., Jones R. T., Stoskoph M., Colwell R. R. "Vibrio species associated with mortality of sharks held in captivity" Microbial Ecology, 10, 271-282, 1984

[13] Çanak Ö., Yardımcı R. E., "Kültürü yapılan denizel türlerin patojeni olan Vibrio harveyi üzerine bir derleme” JournalofFisheriesSciences.com, 5, 131-140, 2011 
[14] Sugita H., Okano R., Suzuki Y., Iwai D., Mizukami M., Akiyama N., Matsuura S., “ Antibacterial abilities of intestinal bacteria from larval and juvenile Japanes flounder against fish pathogens” Fisheries Science, 68, 1004-1011, 2002

[15] Gülay Z., “Antimikrobiyal ilaçlara direnç”, Edited by Mutlu G., İmir T., Cengiz A. T., Ustaçelebi Ş., Tümbay E., Mete Ö., Güneş Kitapevi, İstanbul, Türkiye, 91-108, 1999

[16] Jakaprakash N. S., Pai S. S., Philip R., Singh I. S. B., "Isolation of a pathogenic strain of Vibrio alginolyticus from necrotic larvae of macrobrachium rosenbergii (de Man)” Journal of Fish Diseases, 29, 187-191, 2006

[17] Li J., Lie J., Foo W. T., Ling J. L. M., Xu H., Woo N. Y. S., “Antibiotic resistance and plasmid profiles of Vibrio isolates from cultured silver sea bream, Sparus sabra” Marine Pollution Bulletin, 39, 245-249, 1999

[18] Nakayama T., Ito E., Nomura N., Matsumura M., "Comparison of Vibrio harveyi strains isolated from shrimp farms and from culture collection in terms of toxicity and antibiotic resistance" FEMS Microbiology Letters, 258, 194-199, 2006

[19] Redondo P. N., Jorero J. R., Figueroa J. L. A., López M. L., "Relation between virulence and presence of plasmids in bacteria Vibrio fluvialis and Vibrio furnissi isolated from goldfish (Carassius auratus)” Veterinary Medicine, 37, 29-42, 2006

[20] CLSI (Clinical Laboratory Standards Institute), “ Methods for Antimicrobial Disk Susceptibility Testing of Bacteria Isolated from Aquatic Animals; Approved Guideline” Clinical and Laboratory Standards Institute, 73s, Pennsylvania, 2006

[21] Yanong R. P. E., "Necropsy techniques for fish” Seminars in Avian and Exotic Pet Medicine, 12, 89-105, 2003

[22] Austin B., Austin D. A., "Fish Pathogens Diseases in farmed and Wild Fish" Ellis Horwood, 364s, Chichester, 2007

[23] Seeley W., VanDemark P. J., “ Microbes in Action, A Laboratory Manual of Microbiology” W. H. Freeman and Company, 450 s, New York, 1991

[24] CLSI (Clinical and Laboratory Standards Institute), "Performance Standards for Antimicrobial Disk and Dilution Susceptibility Tests for Bacteria Isolated from Animals; Approved Guideline” Clinical and Laboratory Standards Institute, 70s, Pennsylvania, 2002

[25] Alsina M., Blanch A. R., “A set keys for biochemical identification of environmental Vibrio speccies” Journal of Applied Bacteriology, 76, 79-85, 1994

[26] Farmer J. J. III., Janda J. M., Brenner F. W., Cameron D. N., Birkhead K. M., “Genus I. Vibrio Pacini 1854”, Edited by Brenner B. J., Krieg N. R., Staley J. T., Springer, Berlin, Germany, 454-518, 2005

[27] Noguerola I., Blanch A. R., "Identification of Vibrio spp. with a set of dichotomous key", Journal of Applied Microbiology, 105, 175-185, 2008

[28] Husain M. A., "Bacitracin, glycopeptide antibiotics, and the polymixine”, Edited by Craig C. R., Stitzel R. E., Modern Pharmacology with Clinical Applications, London, UK, 552-556, 2004

[29] Jayasudha J., Kumar G., Karthik L., Rao Bhaskara K. V., "Biological control of vibriosis by antogonistic actinobacteria- an in vitro study”, Journal of Agricultural Technology, 7, 271-280, 2011 
[30] Orozova P., Chikova V., Najdenski H., “Antibiotic resistance of Aeromonas spp.”, Journal of Agricultural Science, 16, 376-386.

[31] Miller R. A., Walker K. D., Baya A., Clemens K., Coles M., Hawke J. P., Henricson B. E., Hsu H. M., Mathers J. J., Oaks J. L., Papapetropoulou M., Reimschuessel R., “Antimicrobial susceptibility of bacteria: quality control disc diffusion ranges for Escherichia coli ATCC 25922 and Aeromonas salmonicida subsp. salmonicida ATCC 33658 at $22{ }^{\circ} \mathrm{C}$ and $28{ }^{\circ} \mathrm{C}$ ”, Journal of Clinical Microbiology, 41, 4318-4323

[32] Smith P., Kronwall G., "Effect of incubation temperature and time on the precision of data generated by antibiotic disc diffusion assays”, Journal of Fish Diseases, 38, 629-636

[33] Korun J., Timur G., "Gökkuşağı alabalıklarında (Oncorhynchus mykiss) fry mortalite sendromu (fms) üzerine bir çalışma”, İstanbul Üniversitesi Su Ürünleri Dergisi, 12, 15-30, 2001 